\title{
The Martinsyde Transatlantic Challenger Monoplane
}

\author{
An English Machine Designed to Compete for the Northcliffe Prize
}

By Major H. Bannerman-Phillips

THE late Mr. Gustav Hamel hoped to attempt a 1 flight across the Atlantic Ocean this summer in an aeroplane built by Martin \& Handasyde.

It was intended that the flight should be made from Newfoundland to Ireland, and the machine was to be ready for trial by the end of June or the beginning of July. Unfortunately, Mr. Hamel's untimely end has led to the abandonment of the entire scheme. The interest in transatlantic flying is such that a description of the machine should be placed on record. The machine was to be of the type, generally speaking, known as the Martinsyde monoplane, and was being constructed in duplicate at Brooklands at the cost of Mr. Mackay Fdgar, the owner of the well-known motor-boat "Maple Leaf."

Mr. Hamel was to have been accompanied by an experienced navigator in the person of some officer of the merchant service who had made many transatlantic voyages, and under whose guidance $\mathrm{Mr}$. Hamel proposed to fly in the track of the liners which are crosspos to fly in the track of the in porica, on the supposition that by following such a course he would seldom be out of sight of a ship. At a height of 1,000 to 1,500 feet any vessel within a radius of 30 miles should be visible in clear weather, and the height to which the machine could ascend was to carry it clear of the fogs on the Newfoundland Banks, which would otherwise have been troublesome at the start.

The estimated speed of the machine in calm weather The to have been 80 to 85 miles per hour, and fuel for 25 hours was to have been carried in a very large gasoline tank of 330 gallons capacity. This, with the wings and a watertight compartment, which in itself was to have a flotational capacity of nearly twice the full load of the machine, was calculated to be capable of sustaining the monoplane on the surface of the sea in case it should have had to come down in mid-Atlantic. There was no intention of descending, however, between start and finish unless necessity or accident compelled such a course. The machine was not a seaplane, and had no floats which would enable it to travel on the surface of the water. Even the wheeled chassis with which it was fitted to enable it to run along the ground in order to gather speed for its first leap into the air, was to be so constructed that the pilot, by pullthe fuselage, and thus reduce the useful load of the monoplane when once clear of the land. There would then remain for landing purposes a large central skid and two lowe king-posts and skids, sufficient for the purpose, since the machine would be much lighter at the end of the journey than at the beginning, on account of the consumption of fuel, and therefore able to make a slow landing.

The accompanying illustrations may be considered to give a fairly correct idea of the monoplane as it would have appeared in mid-air over the Atlantic afte the chassis had been dropped, but some items were still under consideration at the time of Hamel's disappearance. The span of the planes was 66 feet over all, of 14 feet 6 inches chord at the roots of the wings, tapering to 10 feet 6 inches at the tips, with a total urface of about 770 inchare feet, and the trailing edse we the wing between the spars, instead of following a continuous curve, was quite flat. The engine was to be a 12-cylinder Sunbeam of 215 horse-power nominal, which would drive a 4-bladed propeller of 12 feet diameter through a reduction gear. Covered in by a stream-line cowl, carried to the rear of the passengers' seats, the motor was to be fixed in the front of the fuselage. Behind this was a water-tight bulkhead or partition and a second similar bulkhead was fitted about 14 feet further back. Aft of this the construction of the fuselage was of the usual type, with the ordinary struts and braces, but exceptionally strong.

The seats for pilot and navigator were placed side by side, level with the trailing edge of the wings and at the after end of the at the after end of the 14-foot water-tight compartment f this compartment the front spars of the wings cross the upper longerons of the fuselage and about midway the rear spars enter the latter beneath the longerons, the ends of the spars meeting on the center-line. From the points of entrance of the spars into the fuselage a couple of inverted struts started, which met on the central skid. These were to carry the main central skid. the spar butts by means of a pair of longerons at tached to them.

The system of wing-bracing was so designed as to mak of the wings, together with both the upright and inverted struts, bracing-posts and bracing-wires a complete box-girder, with tension applied below as well as above the wings. This should have given a unit of e gasoline tank with its contents. Compared with this the weight of the engine and the human freight was of minor importance. The total weight of the monoplane, full (Concluded on page 34.)

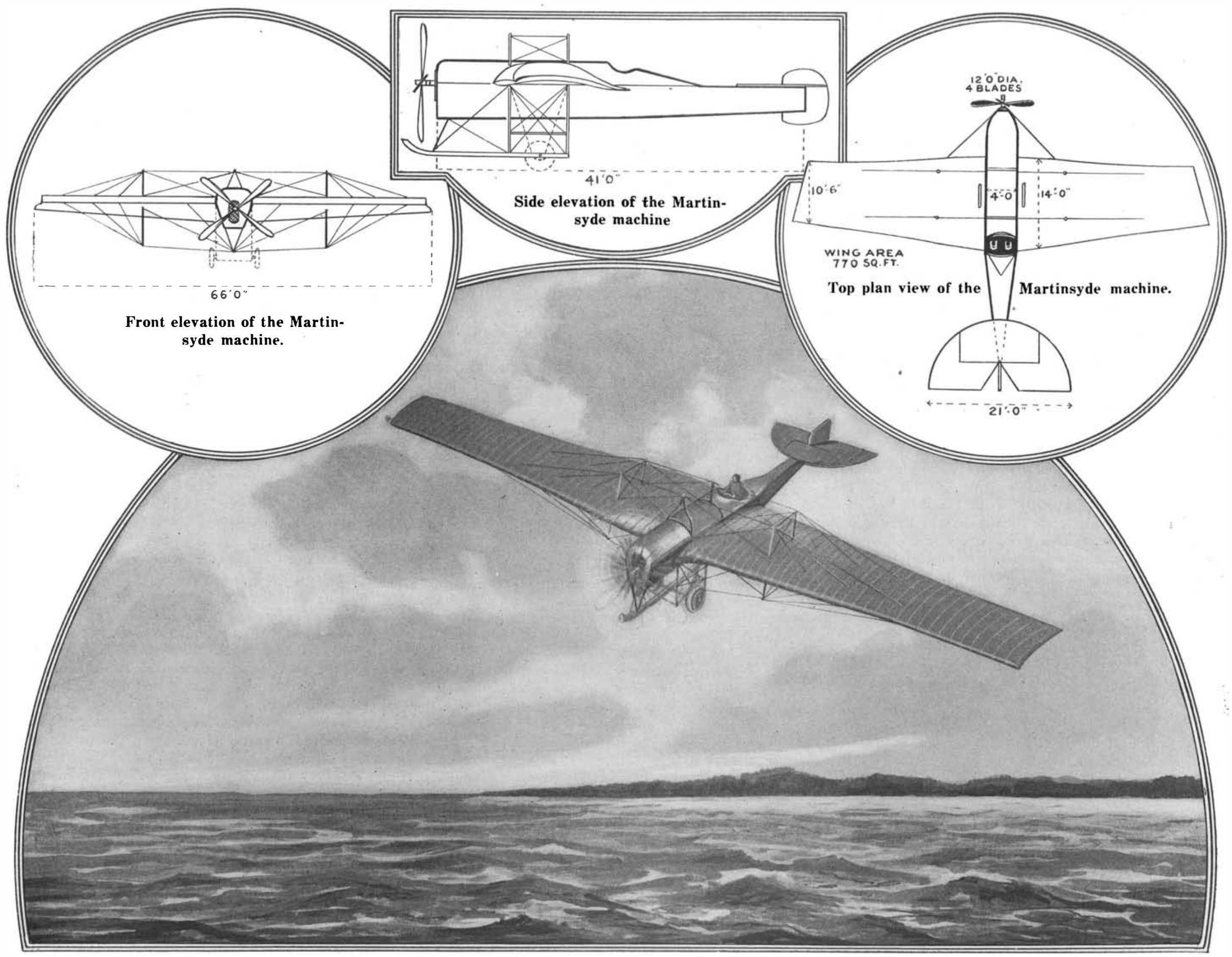

The eighty-mile-an-hour monoplane which the late Gustav Hamel was to have used this summer in an attempt to fly across the Atlantic Ocean from North America to Europe. 


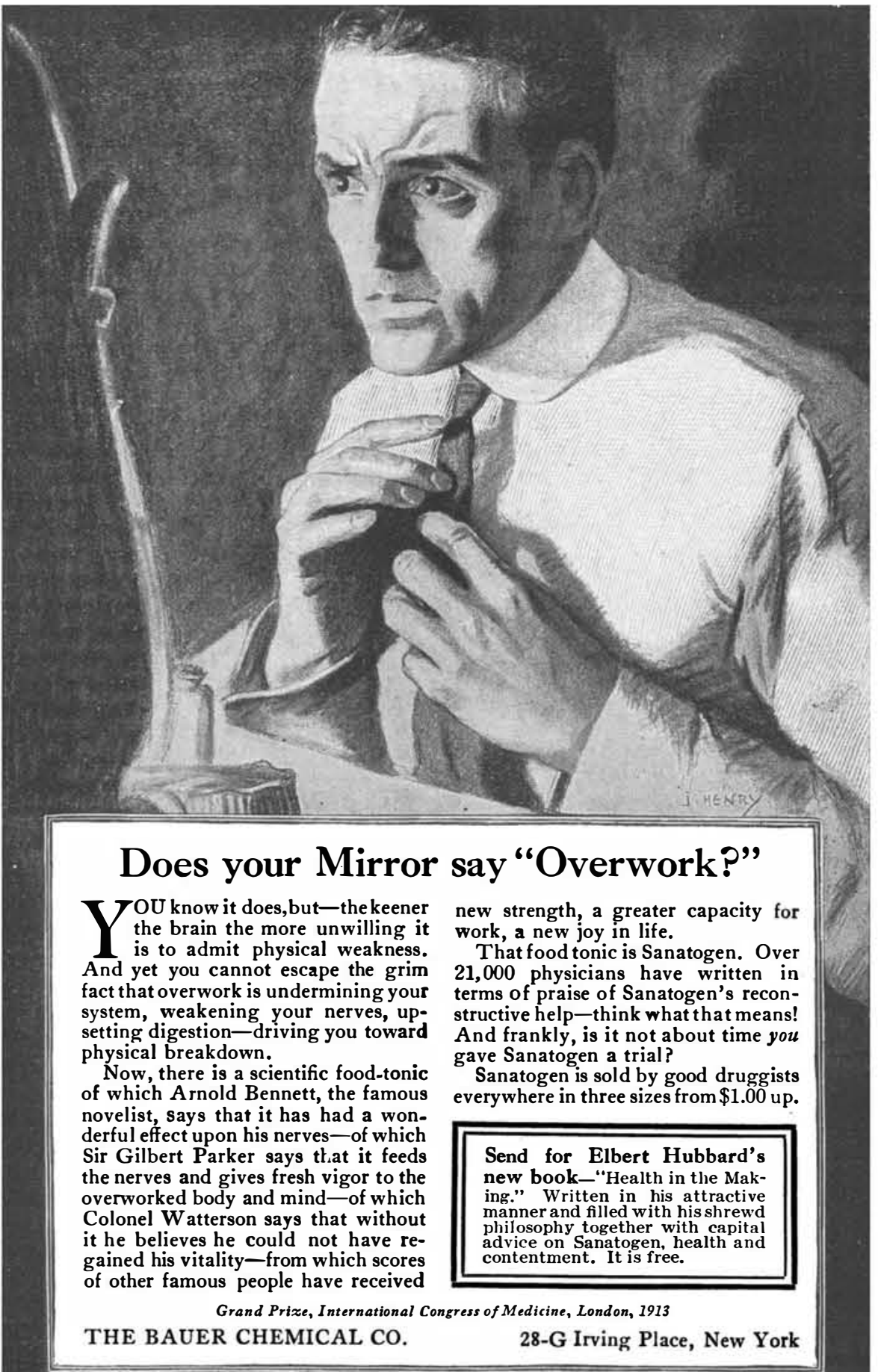

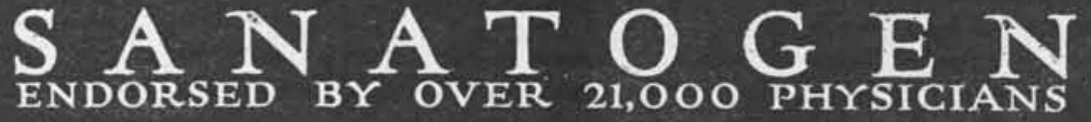
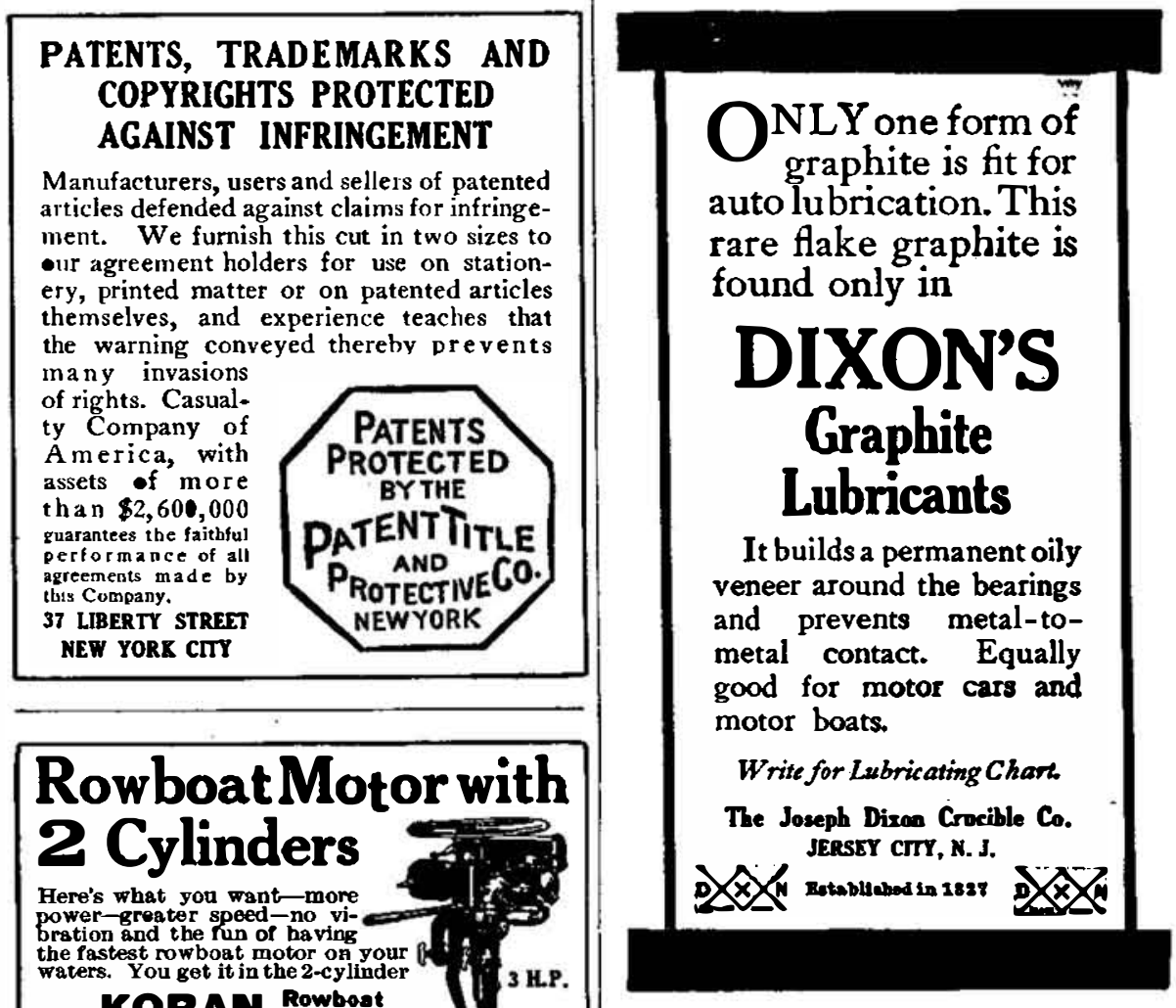

\section{KOBAN Rowbag}

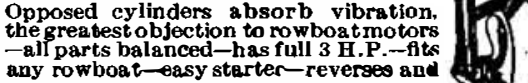

Does not shake the boat

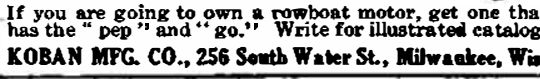
AGENTS - MAKE $\$ 100$ to $\$ 300$

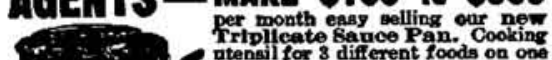

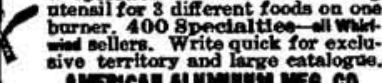

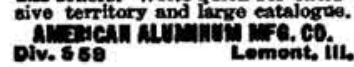

The Martinsyde Transatlantic Chal-

loaded, which was to have been sustained and impelled by the aerodyuamic reaction of the planes and motive power against have been close on to 5,000 pounds. fuselage, and was of semi-circular form in plan, with a span of 21 feet. It had divided and balanced elevator flaps, and a balanced rudder of ample proportions.

It has already been mentioned that the machine was being constructed in duplicate, and it may be added that this duplication applied to the engine, since two separate, but identical engines had been put in hand, and both were to be sent to the starting point in Newfoundland, together with a very full supply of spare to be tuned up for the journey and one was to have been placed in the monoplane and the other kept in reserve as a measure of precaution in the same manner as the duplicate wings and fuselage, etc.

Straits and the coast of Galway in Ire-

land is about sixteen hundred miles, and the aeroplane was expected to travel at that the journey could be done in 20 hours during calm weather. A following wind would have materially increased the speed and shortened the time of the journey.

Eliminating a City's Filth and Flies policemen resorted to the use of polite notes, which were written or printed on fyless. Will you help us? Flles breed in fermenting lawn clippings, open garbage, and
stable manure, if it is not removed at leas Very truly yours, summer? Very sincerely yours, boys and girls like to feel that their work

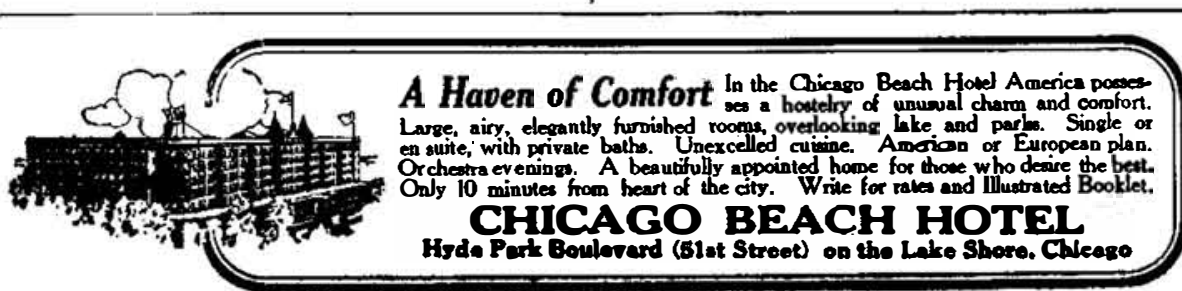

The Germans still maintain the lead in lenger Monoplane

\section{(Concluded from page 24.)}

The tuil was at the after end of the

Since the distance between Belle Is (Concluded from page 29.)

Knowing that he had no police authority, and that his only weapon was his power of persuasion, the junior sanitar a printing outfit that belonged to the neighborhood :

We are trying to make our school district once a week. We are writing this note to you because we are sure that you will help us.

Junior Sanitary Polic

The girls also appealed to the merchants through notes in the same way:

My Dear Mr.

Many people in our school district are refus ing to buy food over which flies have crawled Can we help you to keep a flyless store th

Sanitary Aido.
Children took naturally to the work of ceaning their school district, for even important. When conditions were met for help written in a childish hand-writing and sent to the Street Cleaning De partment was sure to bring assistance whenever it was possible. Before the close of the school year streets were cleaned, alleys and vacant lots ceased to rubbish from back yards gave way to gardens of flowers and vegetables.

Now Aeronautic Records

THE French military dirigible baloon "Adjutant Vincenot," piloted b Georges Joux and carrying eight passengers, has made a new world's record for continuous navigation by dirigibles. It minutes.

The German dirigible "Zeppelin $\mathrm{L}-3$ " established the previous record of 34 hours and 59 minutes in May in a flight from Friedrichshaffen to Berlin. The

I. EG A L NOTICES

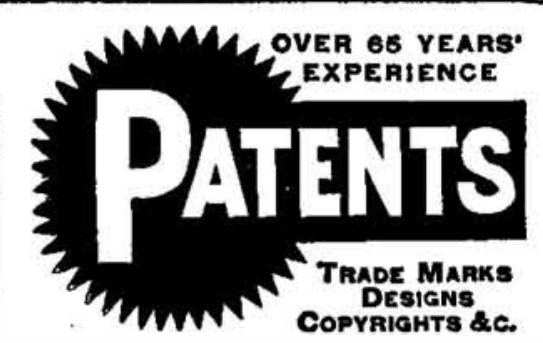

INVENTORS are invited to communicate with Munn \& Co.. 361 Broadway, New York, or
625 F Street, Washington, D. C., in regard to securing valid patent protection for their Inventions, Patents and Foreign Patents secured.

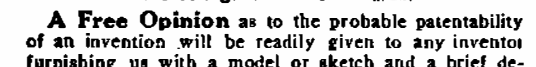
acription of the device in question. All communications
are strictly confdential. Our Hand-Book on Patents Oura is the Oldost agency for securing patente; it
was established over sixty-five years ago. All patents secured through wo are deacribed without
cost to patentee in the Scientific American. MUNN \& CO., 361 Broadway, New York Branch Office 625 F St.. Washington. D.C.

Classified Advertisements

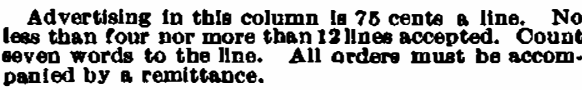

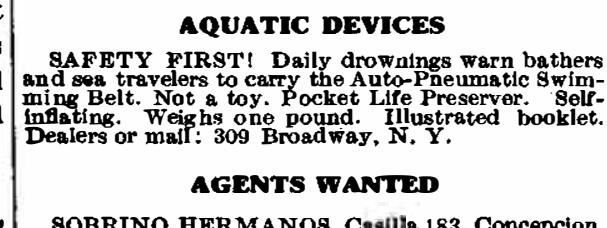
SOBRINO HERMANOS, Casilla 183, Concepcion,
Chile, desire to obtain the agency for Chile for good

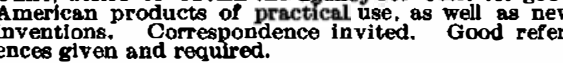
AGENTS. 500\% Prote, Free Sample Gold and
silver Sign Letters for store fronts and offce win-

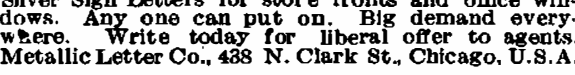
BUSINESS OPPORTUNITIES SUCCESSFOL COMPANY MANUFACTURIN

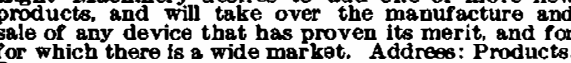
SIDE LINE SALESMEN, ATTENTION! This at once for our live premium proposition. We guar-
anteg our goodd to sell, or take back unsold goods
Writte today for full particulars. Canfleld Mrg. Co. FOR SALE

NINE SUCCESSFUL CHEMICAL FORMULAS

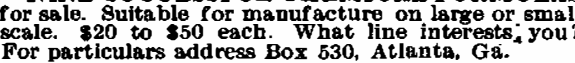

PATENTS FOR SALE

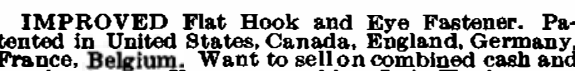

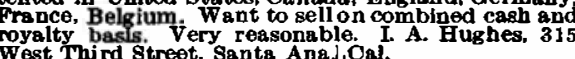
MISCEMIANEOUS MODEL AND EXPERIMENTAL WORK for

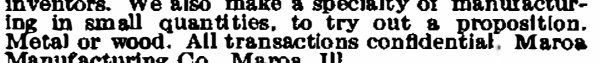
ROTARY PUMPS AND ENGINES Their Orixin and Devolopment

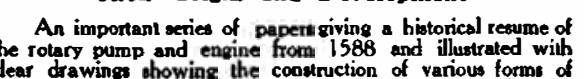

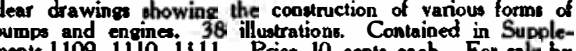

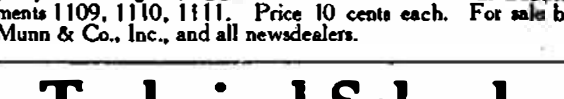
Technical Schools

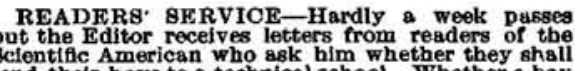
send their boys to a technical schol. Whether a boy
shall become an englneer, a chemist or a naval archl. lect are questions that puzzle parents. The Editor will
be pleased to ald resders of the Sclentfice Americsp
in deciding the matter of thechnical education for Polytechnic Institute of Brooklyn COLLEGE OF ENGINEERING

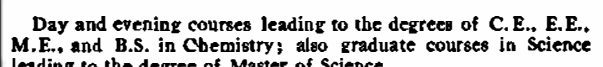
FRED W. A TKINSON, Ph.D., Preaident.

NEW YORK UNIVERSITY SCHOOL OF APPUED SCIENCE measures more than 25,000 cub meters; the "Adjutant Vincenot" 9,000 cubic meters. aviation, particularly from the standpoint of duration. On the 28th ultimo Herr Landmann, with a 75 horse-power Albatross biplane, remained aloft, circling the 49 minutes, thus adding well over three 49 minutes, thus adding well over He finally descended because of fatigue, and not from lack of fuel. Science in Civil Engineering. in Mocking
ginearing and in Chemical Engineering.

Bulletin upon application to
G. C. SPRAGUE, Registrur, Wautientos Sqaare, N. Y. City

LEARN TO BE A WATCHMAKER

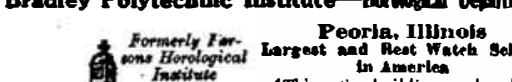

每

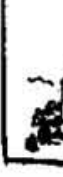

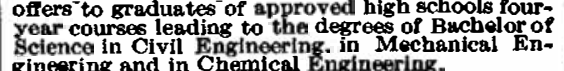

Bradley Polytoche A WATCHMAK 